\title{
In situ detection of DNA and mRNA of human cytomegalovirus to distinguish different forms of viral infection in leukocytes ${ }^{\star}$
}

\author{
Barbara Zawilinska ${ }^{\circledR}$, Katarzyna Bulek ${ }^{2}$, Jolanta Kopec ${ }^{1}$ \\ and Magdalena Kosz-Vnenchak ${ }^{2}$ \\ ${ }^{1}$ Department of Virology, Chair of Microbiology, Jagiellonian University, Medical College, Kraków, Poland; \\ ${ }^{2}$ Faculty of Biotechnology, Jagiellonian University, Kraków, Poland; \\ $\bigotimes_{e-m a i l: m b z a w i l i @ c m-u j . k r a k o w . p l}$
}

Received: 06 June, 2006; revised: 31 August, 2006; accepted: 19 September, 2006 available on-line: 9 October, 2006

\begin{abstract}
In situ PCR and in situ reverse transcription PCR (RT-PCR) were applied to discriminate between latent and productive infection of human cytomegalovirus (HCMV) in leukocytes. We investigated 28 samples, in which viral pp65 antigen was detected only in the cytoplasm of leukocytes. Additionally we assayed 12 specimens lacking pp65 antigen. Using nested PCR (nPCR), viral DNA was detected in 27 samples. In six samples the results of nPCR were unreadable due to the presence of polymerase inhibitors. By application of in situ PCR, we were able to confirm the presence of viral DNA in the nucleus and/or cytoplasm. Productive infection was recognized in 20 samples in which transcripts for late viral genes were detected. Among the 20 samples negative by in situ RT-PCR, we recognized phagocytosis of viral particles in eight and the latent form of HCMV infection in five.
\end{abstract}

Keywords: cytomegalovirus, antigenemia pp65, PCR, in situ PCR, in situ RT-PCR

\section{INTRODUCTION}

Human cytomegalovirus (HCMV) infection remains a major problem in immuno-compromised patients, such as bone marrow or solid organ recipients and those suffering from AIDS (Alford \& Britt, 1996). Following primary infection, HCMV establishes lifelong latency, which is controlled by a functioning immune system. Immunodeficiency leads to increased levels of HCMV replication and can cause severe, life-threatening diseases (Hengel et al., 1998; Streblow \& Nelson, 2003).

Development of a diagnostic test that correctly indicates the risk of HCMV disease is very important in the success of preemptive or prophylactic therapy. Rapid, sensitive, specific and reliable diagnostic assays for HCMV detection are essential for achieving these goals (Boeckh \& Boivin, 1998). Quantitative methods that assess viremia, including antigenemia assay and PCR techniques (DNAemia), are recommended in patients at risk for HCMV disease for early diagnosis and monitoring of antiviral treatment (Schafer et al., 1997; Preiser et al., 2001; Razonable et al., 2002).

The antigenemia assay is based on direct detection of HCMV phosphoprotein 65 (pp65 antigen), which is found in the nucleus of leukocytes during active infection (Gerna et al., 1992; Perez et al., 1994). Our own and those of others observations reveal that pp65 antigen is also found in the cytoplasm quite frequently, which may be a result of phagocytosis or accumulation of virions in the replicative cycle (Kas-Deelen et al., 2001).

To explain this phenomenon we used additional methods such as nested PCR (nPCR) and in situ PCR. Because application of PCR technology for the detection of viral nucleic acid allows one to detect both latent and replicating viral sequences,

^The paper was presented at XXXIII Winter School of Biotechnology „Various Faces of Biotechnology” organized by the Faculty of Biochemistry, Biophysics and Biotechnology Jagiellonian University, 25th February-2nd March 2006, Krynica, Poland.

Abbreviations: gB, glycoprotein B; HCMV, humn cytomega virus; nPCR, nested PCR; pp65, phoshoprotein 65; RT-PCR, reverse transcription PCR. 
this approach should be expanded for the detection of HCMV late transcript, which may better reflect productive viral replication (Taylor-Wiedeman et al., 1991; Gozlan et al., 1992).

\section{MATERIALS AND METHODS}

Clinical specimens. Forty samples of leukocytes obtained from 32 patients after bone marrow transplantation (BMT) in different stages of treatment (1-24 months after transplantation, average 7.0 \pm 6.0) were investigated. Leukocytes were isolated by sedimentation of 3-5 ml EDTA-treated blood samples with $6 \%$ dextran solution (The et al., 1995). The upper part was collected after 30 min incubation at $37^{\circ} \mathrm{C}$ and centrifuged at $600 \times g$ for $15 \mathrm{~min}$. The contaminating erythrocytes were lysed with $0.75 \% \mathrm{NH}_{4} \mathrm{Cl}$ solution at $4^{\circ} \mathrm{C}$ for $10 \mathrm{~min}$. Aliquots of 2 $\times 10^{5}$ leukocytes per slide were used to prepare cytospins. The slides were fixed in $10 \%$ buffered formalin for $4 \mathrm{~h}$ (in situ PCR and in situ RT-PCR) or in $5 \%$ buffered formalin for 15 min (antigenemia pp65). The remaining leukocytes $\left(1 \times 10^{6}\right.$ cells $)$ were used to obtain DNA, which was isolated using Genomic DNA Prep Plus (A \& A Biotechnology).

pp65 antigenemia. Monoclonal antibodies NCL-HCMV pp65 (Novocastra) were used. The HCMV pp65 antigen was detected according to Gerna et al. (1992).

Nested PCR. Two pairs of primers to amplify the gene encoding viral glycoprotein $\mathrm{B}(\mathrm{gB})$ according to Mitchel et al. (1994) were used. The "outer" set was 5'-GTCGACGGTGGAGATACTGCTGAGG$3^{\prime}$ and $5^{\prime}$-GAGGACAACGAAATCCTGTTGGGCA3', which amplifies a $150 \mathrm{bp}$ sequence. The "inner" primer pair was 5'-ACCACCGCACTGAGGAATGT-

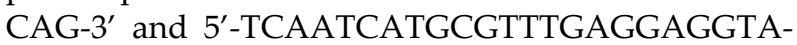
$3^{\prime}$, which amplifies a $100 \mathrm{bp}$ sequence.

The material for amplification was $20 \mathrm{ng}$ of DNA isolated from leukocytes. The reaction took place in a thermocycler (Biometra) in buffer containing 10 $\mathrm{mM}$ Tris/ $\mathrm{HCl}, \mathrm{pH}$ 8.3, $50 \mathrm{mM} \mathrm{KCl}, 1.5 \mathrm{mM} \mathrm{MgCl}{ }_{2}$, $1 \mathrm{U}$ of Taq polymerase DyNAzyme ${ }^{\mathrm{TM}}$ (Finnezymes), $200 \mu \mathrm{M} d \mathrm{NTP}$ and $100 \mathrm{ng}$ of each primer. Samples were amplified for 35 cycles under the following conditions: $94^{\circ} \mathrm{C}$ for $5 \mathrm{~min}$ (first denaturation), $95^{\circ} \mathrm{C}$ for 2 min, $58^{\circ} \mathrm{C}$ for external primers and $50^{\circ} \mathrm{C}$ for internal primers for $2 \mathrm{~min}, 72^{\circ} \mathrm{C}$ for $1 \mathrm{~min}$, followed by a final elongation step of $72^{\circ} \mathrm{C}$ for $7 \mathrm{~min}$. All amplifications were carried out with negative and positive controls. A check for the presence of Taq DNA polymerase inhibitors was performed by adding 2 ng of DNA (obtained from a cell culture infected with the AD-169 strain of HCMV) to the negative samples and retesting. The PCR products were visualized by electrophoresis in $2 \%$ agarose gel with ethidium bromide.
In situ PCR. In situ PCR was done according to the protocol based on Lewis (1996) and Nuovo (1996). The appropriate sample was digested with pepsin (2 $\mathrm{mg} / \mathrm{ml}$ ) for $30 \mathrm{~min}$ and afterwards inactivated in $100 \%$ ethanol. The reaction was carried out in a thermocycler (Perkin Elmer). A volume of $25 \mu \mathrm{l}$ of reaction mixture was applied onto the slide. The mixture contained $1 \mu \mathrm{M}$ primers; $200 \mu \mathrm{M}$ nucleotides; $20 \mu \mathrm{M}$ digoxigenin-labeled dUTP (DIG-dUTP, Applied Biosystems); 4.5 or $5 \mathrm{mM} \mathrm{MgCl}{ }_{2}, 0.2 \mathrm{U} / \mu$ l polymerase Taq IS or Stoffel Fragment and $1 \times$ buffer $(\mathrm{pH} 8.3,100 \mathrm{mM}$ Tris/ $\mathrm{HCl}, 500 \mathrm{mM} \mathrm{KCl} / 10 \times$ ) for IS polymerase or $1 \times$ buffer ( $\mathrm{pH}$ 8.3, $100 \mathrm{mM}$ Tris/HCl, $100 \mathrm{mM} \mathrm{KCl} / 10 \times$ ) for Stoffel Fragment. A suitable concentration of magnesium chloride was established, $4.5 \mathrm{mM}$ and $5 \mathrm{mM}$ for IS polymerase and Stoffel Fragment, respectively. In addition to the primers for the gene coding for $\mathrm{gB}$, primers for the gene encoding phosphoprotein pp65 (fluorescently labeled) were also used (Zaia et al., 2001). The "outer" primers were MP1 (5'-CTCGTAACCACCGAGCGCAAG-3') and AP4 (5'-TCAACCTCGGTGCTTTTTGGGCG-3'), the "inner" primers RAP1 (5'-GGATTCCGACAACGAAATCCAC-3') and AP5 (5'-ATACGCTTCCAATTCGGCGAA-3') yielding PCR products of $458 \mathrm{bp}$ in the first run and $171 \mathrm{bp}$ in the second.

For amplification of the target sequences, a modified program of two cycles was used: $94^{\circ} \mathrm{C}$ for $3 \mathrm{~min}$ in the first cycle, and 20 repetitions of $94^{\circ} \mathrm{C}$ for $45 \mathrm{~s}$ and $60^{\circ} \mathrm{C}$ for $1.5 \mathrm{~min}$ in the second cycle (Nuovo, 1996). The hapten, incorporated into the amplified product, was detected using anti-digoxigenin antibodies conjugated to alkaline phosphate. The signal, resulting from the activity of the alkaline phosphate in the presence of nitroblue tetrazolium (NBT) and 5-bromo-4-chloro-3-indolyl phosphate (BCIP), was obtained according to the manufacturer's instructions (Boehringer Mannheim). The signal resulting from fluorescein was detected under a fluorescent microscope.

In situ RT-PCR. Samples were prepared in the same way as for in situ PCR. After pepsin treatment the samples were incubated in DNase solution $(1 \mathrm{U} / \mu \mathrm{l})$ at $37^{\circ} \mathrm{C}$ for $12 \mathrm{~h}$. Reaction was carried out in the thermocycler (Perkin Elmer), $25 \mu \mathrm{l}$ of reaction mixture was applied onto the slide. The mixture contained $1 \times$ buffer EZ (Applied Biosystems), $4 \mathrm{mM} \mathrm{MnCl} 2,300 \mu \mathrm{M}$ dNTP, $15 \mu \mathrm{M}$ DIG-dUTP, $1 \mu \mathrm{M}$ of each primer specific for $\mathrm{gB}, 0.2 \mathrm{U} / \mu \mathrm{l}$ rTth DNA polymerase, which has both polymerase and reverse transcriptase activity (Applied Biosystems), $0.5 \mathrm{U} / \mu \mathrm{l}$ RNasin (Applied Biosystems). The RT-PCR assay was performed under the following conditions: $65^{\circ} \mathrm{C}$ for $30 \mathrm{~min}$, preliminary denaturation at $94^{\circ} \mathrm{C}$ for $3 \mathrm{~min}, 20$ cycles at $60^{\circ} \mathrm{C}$ for $1.5 \mathrm{~min}$ and $94^{\circ} \mathrm{C}$ for $45 \mathrm{~s}$. Detection was carried out in the same way as for in situ PCR. 


\section{RESULTS}

In 28 samples of peripheral leukocytes, pp65 antigen was present in the cytoplasm (Fig. 1). Among the 12 samples without the pp65 antigen, two were obtained from seronegative recipients without history of HCMV infection. They were used as a negative control. All 40 samples were retested using nPCR, in situ PCR and in situ RT-PCR. Additionally, we used controls without polymerase or primers, which were helpful in correct interpretation of the results in the "in situ" methods. In some cases this evaluation was essential because of the repair ability of DNA polymerase. The results obtained by pp65 antigenemia, nPCR, in situ PCR and in situ RT-PCR are presented in Table 1. Using nPCR, viral DNA was detected in 27 clinical specimens, seven samples were negative. In the remaining six samples the results were unreadable due to the presence of polymerase inhibitors. The amplification results of these specimens in the presence of $2 \mathrm{ng}$ of DNA positive for HCMV were also negative. In 20 blood samples we detected the viral DNA in the nucleus and/or cytoplasm of investigated cells by in situ PCR. In the same samples we found late viral transcripts using in situ RT-PCR, which confirmed productive infection. Figures 2 and 3 show examples of the results obtained with in situ PCR using different techniques of visualizing positive signal. Figure 2 shows results of in situ PCR with primers for the gene coding for the protein $\mathrm{gB}$ detected with anti-digoxigenin antibodies conjugated to alkaline phosphatase. Figure 3 shows results of in situ PCR with fluorescently labeled primers for the UL83 gene, coding for late pp65 protein. Figure 4 shows result of in situ RT-PCR reaction with primers for the gene encoding gB.

In eight pp65-positive samples in which the in situ RT-PCR results were negative the presence of CMV antigen in the cytoplasm could probably be due to phagocytosis (the presence of DNA in the cytoplasm was also detected by in situ PCR - Fig. 3).

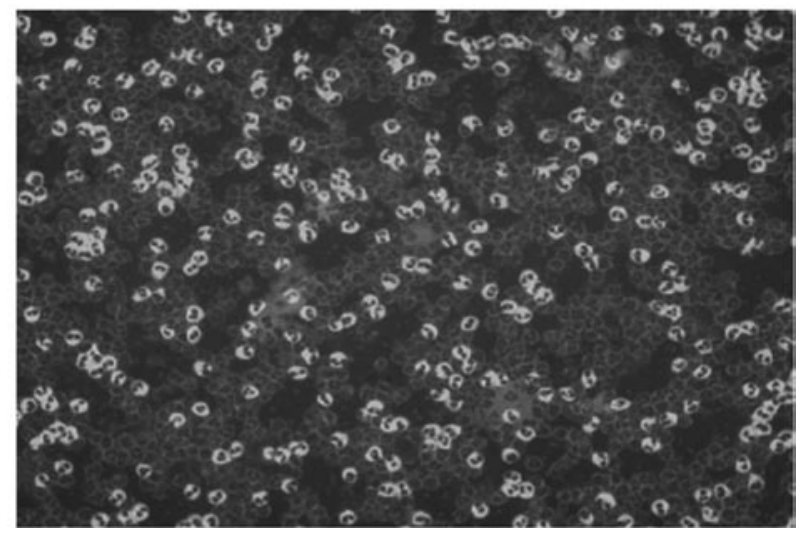

Figure 1. Example of HCMV pp65-antigen presence in the cytoplasm of peripheral blood leukocytes in cytospin preparation-immunofluorescein staining (magnification 250×).

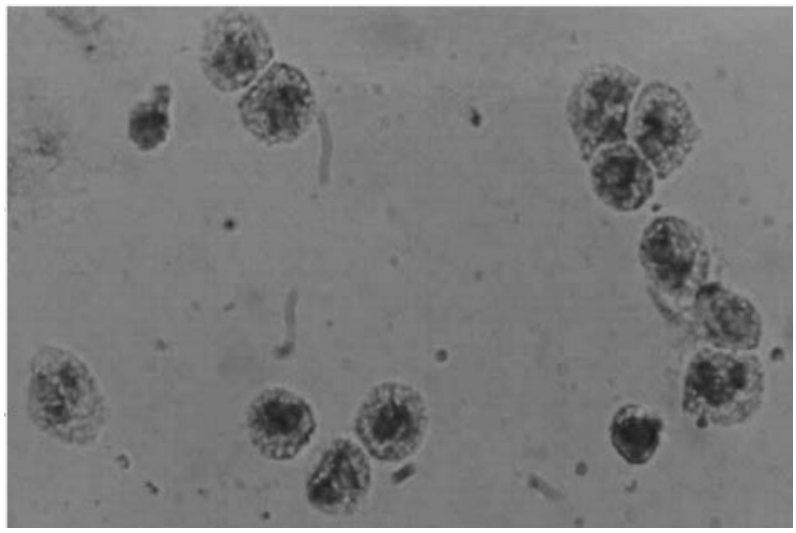

Figure 2. The presence of HCMV DNA in the nucleus of peripheral blood leukocytes obtained by in situ PCR with primers specific for gene coding for gB HCMV (magnification 400x).

Among antigenemia-negative specimens, the latent form of HCMV was recognized in five samples on the basis of HCMV DNA presence in the nucleus (Fig. 2) and absence of transcripts for late viral genes (gB) using the in situ methods.

Table 1. Results of HCMV DNA or mRNA detection in 40 blood samples obtained by three methods, as related to the presence or absence of pp65 antigen in cytoplasm of leukocytes.

\begin{tabular}{|c|c|c|c|c|c|}
\hline Conclusion of investigation & No. of samples & Ag pp65 & nPCR & PCR in situ & RT-PCR in situ \\
\hline \multirow{2}{*}{ Productive infection } & 15 & + & + & $+\left(\mathrm{N} / \mathrm{C}^{*}\right)$ & + \\
\hline & 5 & + & $\operatorname{inh}^{* *}$ & $+(\mathrm{N} / \mathrm{C})$ & + \\
\hline \multirow{2}{*}{ Phagocytosis } & 7 & + & + & $+(\mathrm{C})$ & - \\
\hline & 1 & + & inh & $+(\mathrm{C})$ & - \\
\hline Latent infection & 5 & - & + & $+(\mathrm{N})$ & - \\
\hline Lack of infection & 5 & - & - & - & - \\
\hline Negative control & 2 & - & - & - & - \\
\hline
\end{tabular}

+, positive result; -, negative result; *signal localization: N, nucleus; C, cytoplasm; ${ }^{* *}$ inhibitors of PCR reaction 


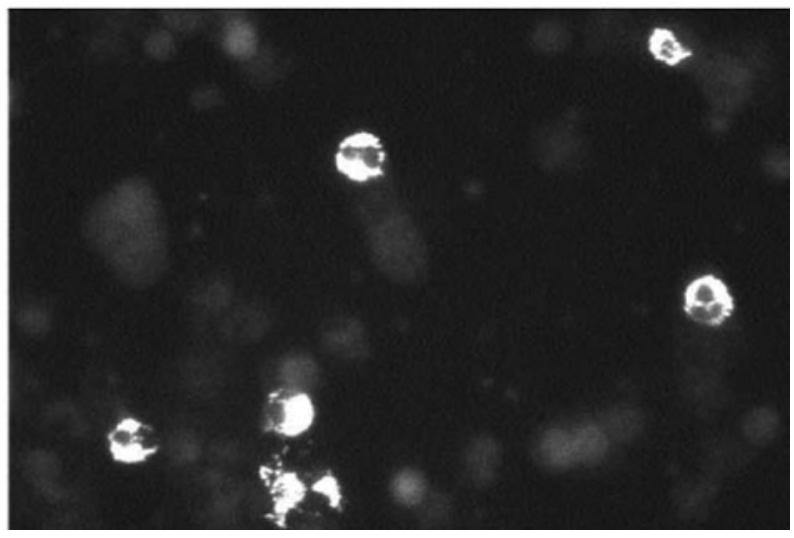

Figure 3. The presence of HCMV DNA in the cytoplasm of peripheral blood leukocytes obtained by in situ PCR with fluorescently labeled primers specific for UL83 gene encoding pp65 protein (magnification 400×).

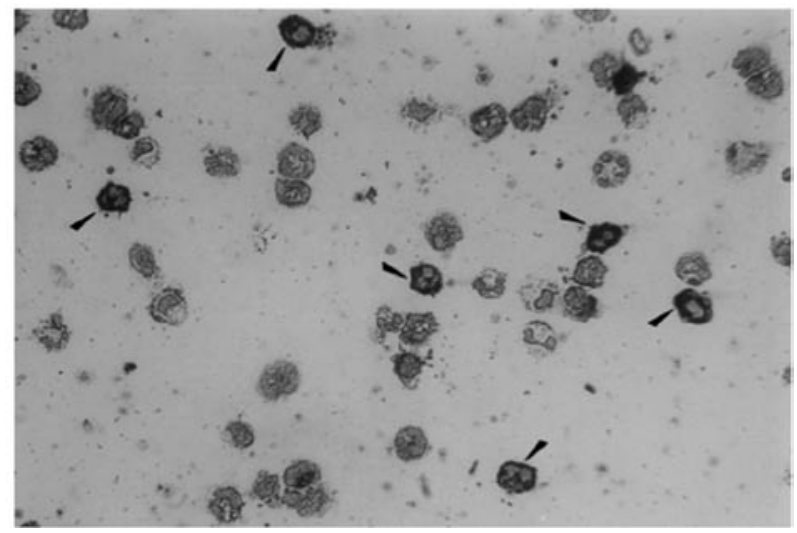

Figure 4. The presence of HCMV transcripts in the cytoplasm of blood leukocytes obtained by in situ RTPCR with primers for gene coding for $\mathrm{gB}$ (magnification 400×).

\section{DISCUSSION}

In immunocompromised patients, especially after organ transplantation, rapid, sensitive and reliable detection of HCMV infection is necessary (Amorim et al., 2001).

Quantitative pp65 - antigenemia assay is regarded as a valuable and sensitive tool for predicting HCMV disease although interpretation of its results is not straightforward. Most instructions recommend recording cells with only nuclear fluorescence. In our prior study such cells were found rarely, mainly in patients with symptoms of HCMV disease, while leukocytes with a positive signal in the cytoplasm occurred quite frequently (Piatkowska-Jakubas et al., 2003). In such cases we used additional tests, in situ PCR and in situ RT-PCR, which confirmed the results of our antigenemia test and explained the source of the pp65 antigen in the cytoplasm of leukocytes. On the basis of the in situ methods, in eight samples we detected the antigen that could be derived by phagocytosis.

Nested PCR with its high sensitivity is useful as a screening test but this approach cannot discriminate between latent and productive infection. In this situation it should be supplemented with quantitative methods or detection of specific viral transcripts as well as in situ methods (Gerna et al., 2000; KoszVnenchak et al., 2001; Yakushiji et al., 2002; Nitsche et al., 2003; Ikewaki et al., 2005).

In situ PCR is the coupling of a PCR assay and nucleic acid hybridization. It allows for detection and visualization of the nucleic acid in question within leukocytes, in the nucleus or cytoplasm (Komminoth \& Long, 1995; Kosz-Vnenchak et al., 2001). This is important for confirmation of latent infection, especially when other results are ambiguous. We confirmed five such cases with latent infection, which we used as negative controls. In situ PCR makes it possible to achieve high sensitivity, but it may cause non-specific signals as a result of mispriming, DNA repair or diffusion of the product (Komminoth \& Long, 1995). Because of this, one should carry out control experiments in order to evaluate the results in a proper way. In using in situ methods the main problem was high background.

The presence of viral mRNA is considered the most important indicator of active viral replication (Gozlan et al., 1992; Deiman et al., 2002). In our study, in situ RT-PCR detecting late HCMV transcripts, such as mRNA for glycoprotein $\mathrm{gB}$, was used to confirm productive viral infection. In 20 samples we detected active HCMV replication and in 13 specimens phagocytosis or latency was probable. In all these cases in situ methods were very helpful. In samples in which it was impossible to carry out $\mathrm{nPCR}$ because of the presence of polymerase inhibitors, the in situ methods played a crucial role in proper diagnosis.

\section{Acknowledgement}

This research was supported by grant 3 P04C 02325 from the Ministry of Scientific Research and Information Technology.

\section{REFERENCES}

Alford CA, Britt WJ (1996) Cytomegalovirus. In Virology (Fields BN, Knipe DM, eds) pp 2494-2512, LippincottRaven Publishers, Philadelphia.

Amorim ML, Cabeda JM, Seca R, Mendes AC, Castro AP, Amorim JM (2001) Cytomegalovirus infection of liver transplant recipients; comparison of antigenemia and molecular biology assays. Liver Transplant 11: 10041007. 
Boeckh M, Boivin G (1998) Quantitation of CMV; methodological aspects and clinical applications. Clin Microbiol Rev 3: 533-554.

Deiman B, van Aarle P, Sillekens P (2002) Characteristics and applications of nucleic acid sequence-based amplification (NASBA). Mol Biotech 20: 163-179.

Gerna GM, Revello G, Percivalle E, Morini F (1992) Comparison of different immunostaining techniques and monoclonal antibodies to the lower matrix phosphoprotein (pp65) for optimal quantification of human cytomegalovirus antigenemia. J Clin Microbiol 30: 12321237.

Gerna G, Baldanti F, Pesea M, Alessandrino E, Pagani A, Locatelli F, Middeldorp J, Revello MG (2000) Human cytomegalovirus immediate early mRNA detection by nucleic acid sequence-based amplification as a new parameter for preemptive therapy in bone marrow transplant recipients. J Clin Microbiol 38: 1845-1853.

Gozlan J, Caburet F, Trancrede C, Petit JC (1992) A reverse polymerase chain reaction method for detection of human cytomegalovirus late transcripts in cells infected in vitro. J Virol Methods 40: 1-10.

Hengel H, Brune B, Koszinowski UH (1998) Immune evasion by cytomegalovirus-survival strategies of a highly adapted opportunist. Trends Microbiol 6: 190-197.

Ikewaki J, Ohtsuka E, Kawano R, Ogata M, Kikuchi H, Nasu M (2005) Real-time PCR assays based on distinct genomic regions for cytomegalovirus reactivation following hematopoietic stem cell transplantation. Bone Marrow Transplant 35: 403-410.

Kas-Deelen AM, The TH, Bloom N, van der Strate BW, De Maar EF, Smit J, van Son WJ, Harmsen MC (2001) Uptake of pp65-positive polymorphonuclear cells mediated by phagocytosis and cell fusion? Intervirology 44: 8-13.

Komminoth P, Long AA (1995) In situ polymerase chain reaction-methodology, application and non-specific pathways. In PCR Applications Manual, pp 99-106, Boehringer Mannheim $\mathrm{GmbH}$.

Kosz-Vnenchak M, Grabiec A, Zawilinska B (2001) Application of PCR in situ method for detection of HCMV DNA. Acta Microbiol Pol 2: 169-173.

Lewis F (1996) An Approach to in situ PCR. PE Applied Biosystems, A Division of The Perkin-Elmer Corporation.

Mitchell SM, Fox JD, Tedder RS, Gazzard BG, Lightman S (1994) Vitrous fluid sampling and viral genome detection for the diagnosis of viral retinitis in patients with AIDS. J Med Virol 43: 336-340.

Nitsche A, Oswald O, Schetelig J, Radonic A, Thulke S, Siegert W (2003) Quantitative real-time PCR compared with pp65 antigen detection for cytomegalovirus (CMV) in 1122 blood specimens from 77 patients after allogenic stem cell transplantation: which test bet- ter predicts CMV disease development? Clin Chem 49: 1683-1685.

Nuovo GJ (1996) PCR in situ Hybridization. Protocolos and Applications, 3th edn, Lippincott, Raven Press New York.

Perez JL, Mariscal D, Tubau F, Niubo J, Martin R (1994) Evaluation of the CMV-vue antigenemia assay for rapid detection of cytomegalovirus in peripheral blood leukocytes. Diagn Microbiol Infect Dis 19: 15-18.

Piatkowska-Jakubas B, Zawilinska B, Kopec J, Rojek-Zakrzewska D, Koprynia M, Polus A, Skotnicki A (2003) Antigenemia pp65 assay and qualitative CMV DNA PCR assay for monitoring cytomegalovirus infection in allogeneic stem cell transplant recipients-own experience. Acta Haematol Polon 34: 339-346.

Preiser W, Bräuninger S, Schwerdtfeger R, Ayliffe U, Garson JA, Brink NS, Franck S, Doerr HW, Rabenau HF (2001) Evaluation of diagnostic methods for the detection of cytomegalovirus in recipients after allogenic stem cell transplants. J Clin Virol 20: 59-70.

Razonable RR, Paya CV, Smith TF (2002) Role of the laboratory in diagnosis and management of cytomegalovirus infection in hematopoietic stem cell and solidorgan transplant recipients. J Antimicrob Chemoter 49: 243-253.

Schafer P, Tenschert W, Gutensohn K, Laufs R (1997) Minimal effect of delayed sample processing on results of quantitative PCR for cytomegalovirus DNA in leukocytes compared to results of an antigenemia assay. J Clin Microbiol 35: 741-744.

Streblow DN, Nelson JA (2003) Models of HCMV latency and reactivation. Trends Microbiol 7: 293-295.

Taylor-Wiedeman JA, Sissons JPG, Borysiewicz IK, Sinclair JH (1991) Monocytes are a major site of persistence of human cytomegalovirus in peripheral blood mononuclear cells. J Gen Virol 72: 2059-2064.

The $\mathrm{TH}$, van der Berg $\mathrm{AP}$, Harmsen $\mathrm{MC}$, van der Bij $\mathrm{W}$, van Son WJ (1995) The cytomegalovirus antigenemia assay: a plea for standarization. Scan J Infect Dis 99: 25-29.

Yakushiji K, Gondo H, Kamezaki K, Shigematsu K, Hayashi S, Kuroiwa M, Taniguchi S, Ohno Y, Takase K, Numata A, Aoki K, Kato K, Nagafuji K, Shimoda K, Okamura T, Kinukawa N, Kasuga N, Sata M, Harada M (2002) Monitoring of cytomegalovirus after allogenic stem cell transplantation: comparison of an antigenemia assay and quantitative real-time polymerase chain reaction. Bone Marrow Transplant 29: 599-606.

Zaia JA, Gallez-Hawkins G, Li X, Yao ZQ, Lomeli N, Molinder K, La Rosa C, Diamond DJ (2001) Infrequent occurrence of natural mutations in the pp65 ${ }_{495-503}$ epitope sequence presented by HLA A*0201 allele among human cytomegalovirus isolates. J Virol 5: 2472-2474. 